\title{
Typological features of water structures of the Railway in West Siberian Urban territories
}

\author{
Eugenia Ketova ${ }^{1,{ }^{*}}$ and Juliya Nizhegorodskaya ${ }^{1}$ \\ ${ }^{1}$ Novosibirsk State University of Architecture and Civil Engineering, 630099 Novosibirsk, Russia
}

\begin{abstract}
The railway construction was a new phenomenon for Russia and was not sufficiently studied from a technological point of view. Primarily, climatic and geographical factors were the main problems in the process of the Trans-Siberian Railway construction. Severe winter, permafrost, mountainous, abundant forest terrain created certain difficulties during the construction phase. Therefore, the builders were forced to violate the nature integrity and lay the railway lines along the most profitable routes. The railway line was naturally chosen, first it should pass through large settlements, and secondly, the important factor was the location of the station near the water source for the uninterrupted operation of locomotives. But together with technological progress, this system was evolved into a complex organism, which parts were modernized, and some of them turned into inefficient structures that are collapsing and polluting the environment.
\end{abstract}

\section{Introduction}

One of the main ecological relationship types between a person and water is his water use through the implementation of individual or centralized water supply. Long-term development of water supply technology is allowed to improve methods of water intake and transportation, which led to some elements inefficiency in the water supply system. Each year, an unprotected object comes to decay, collapsing enclosing structures, facade elements, roofing, and foundation; damage not only environment, but also a danger to humans.

The purpose of this work is to identify inefficient water supply facilities in the railroad water supply system along the West Siberian railway and compile their common base of typological features for further recommendations on their redevelopment.

Russian scientists and engineers created many remarkable works in the field of railroad water supply and hydraulics. In the "On water supply on the railways" work, A.P. Borodin gives a comprehensive analysis of various important issues of water supply. The multidimensional nature of the quality problem and structures improvement in the railroad water supply system is covered in Professor Genius N.N. works. (Geniev N.N. 1929). Valuable contributions to the science development of the railway water supply were made by such scientists as A.A. Surin, doctor of technical sciences, prof. S.H. Azeri, cand. techn. Sciences, associate Professor L.F. Komyagin. A number of valuable proposals for railroad

\footnotetext{
* Corresponding author: michmacha@mail.ru
} 
water supply improvement were made by innovator engineers A.I. Lazarev, A.G. Saveliev, A.F. Revenko, P.P. Surkov, P.A. Anishkin, A.E. Belan and others. [1,2,3,8]

In the of R.B. Konchakov work the problem of ecology and the influence of the railway raises. (Konchakov, R.B.2012) [4-7]

The objects of research were the West-Siberian railway water towers (Line OmskMariinsk). The chronological scope of the research originates from the section of the West Siberian Trans-Siberian Railway construction and until the middle of the 20th century.

The methodology of this study is based on the principles, which consist of a comprehensive study of the West Siberian Railway industrial heritage development, archival and bibliographic research, study of water towers' architectural and planning types and determination of their role in the railway system. In the course of practical and scientific work, the town-planning and architectural history of cities was studied, the typology of industrial heritage and associated constructive techniques, compositional means and stylistic evolution of objects were analyzed.

\section{Materials and Methods}

The typological series of waterworks study gives an opportunity for redevelopment recommendations. Typological features for these objects are: the central location in the station structure, the diameter of 8 meters internal space, the unique appearance, the height of the object. All these features can serve to create a corporate design RRW code and museum cluster in the Siberian region. As a result of the research, a typological series of the West Siberian Railway water structures was formed. Typological features are reflected in Table 1. In addition, regularities in the water-supply location's structures along the West Siberian Railway were revealed. Let us consider various forms and types of the West Siberian Railway water-power structures.

Table 1. Typological features of the West Siberian railway water towers (Omsk-Mariinsk).

\begin{tabular}{|c|c|c|}
\hline \multirow{2}{*}{ Name of station } & \multicolumn{2}{|c|}{ Typological features of the structure } \\
\cline { 2 - 3 } & $\begin{array}{c}\text { Volume-planning and architectural } \\
\text { style solutions }\end{array}$ & Design features \\
\hline 1). Omsk Pass-fat & $\begin{array}{c}\text { The object's tiers are separated by a } \\
\text { cornice belt and processed by } \\
\text { horizontal brick rust. The crowning } \\
\text { cornice of the tower is wide, multi- } \\
\text { stage. The windows of all three } \\
\text { tiers and the entrance aperture with } \\
\text { arched endings are framed by wide } \\
\text { archivolts, laid out from the wedge } \\
\text { brick, with a large castle stone. }\end{array}$ & $\begin{array}{c}\text { Brick, tent tower, heated in } \\
\text { the winter season. } \\
\text { Typical project }\end{array}$ \\
\hline 2). Tatar & $\begin{array}{c}\text { Projecting cornices } \\
\text { and frieze along the } \\
\text { perimeter of the } \\
\text { building. }\end{array}$ & $\begin{array}{c}\text { Brick, tent tower, heated in } \\
\text { the winter season. }\end{array}$ \\
\hline There is a light flashlight.
\end{tabular}




\begin{tabular}{|c|c|c|c|}
\hline 3). Vans & \multicolumn{2}{|c|}{$\begin{array}{l}\text { Adorned with a narrow strip of } \\
\text { cutaway thread, the upper tier is } \\
\text { trimmed and supported by a } \\
\text { massive reinforced belt with multi- } \\
\text { stage consoles with frieze and } \\
\text { window openings in the tent. }\end{array}$} & $\begin{array}{l}\text { Brick trunk with a wooden } \\
\text { tent, heated in the winter. }\end{array}$ \\
\hline $\begin{array}{l}\text { 4). } 2958 \mathrm{~km} \\
\text { (formerly } \\
\text { Koshkul) }\end{array}$ & \multirow{2}{*}{$\begin{array}{l}\text { Wooden carved } \\
\text { clypeus on window } \\
\text { openings along the } \\
\text { perimeter of the } \\
\text { tent. Rust around } \\
\text { the perimeter of the } \\
\text { doorway. }\end{array}$} & & $\begin{array}{l}\text { Brick trunk with wooden } \\
\text { tent. }\end{array}$ \\
\hline & & & Brick, plastered tent tower. \\
\hline 5). Korshula & \multicolumn{2}{|c|}{$\begin{array}{l}\text { Massive protruding pilasters along } \\
\text { the perimeter of the trunk. }\end{array}$} & $\begin{array}{l}\text { Brick trunk, wooden tent. } \\
\text { Heated in the winter season. } \\
\text { There is a light flashlight. }\end{array}$ \\
\hline 6). Ubinskaya & $\begin{array}{l}\text { Castle stone on the } \\
\text { window and } \\
\text { doorway. } \\
\text { Protruding cornice } \\
\text { and frieze along the } \\
\text { perimeter of the } \\
\text { building. }\end{array}$ & & $\begin{array}{l}\text { Brick trunk, wooden tent. } \\
\text { Heated in the winter season. } \\
\text { In a complex with a boiler } \\
\text { room. }\end{array}$ \\
\hline $\begin{array}{l}\text { 7). Novosibirsk- } \\
\text { Main }\end{array}$ & \multicolumn{2}{|c|}{$\begin{array}{l}\text { A tie is placed on the brackets } \\
\text { between the upper and lower part, } \\
\text { above the entrance, connected by } \\
\text { two arches, with a window opening } \\
\text { for illumination of the interior } \\
\text { space and ending with a triangular } \\
\text { pediment. } \\
\text { The cornices are decorated with } \\
\text { saw thread. }\end{array}$} & $\begin{array}{c}\text { Кирпичная, шатровая } \\
\text { башня, отапливаемая в } \\
\text { зимний сезон. } \\
\text { Типовой проект } \\
\text { Кирпичный ствол, } \\
\text { деревянный шатер. }\end{array}$ \\
\hline 8). Tutalian & \multicolumn{2}{|c|}{$\begin{array}{l}\text { In connection with the upper tier } \\
\text { absence, the abutment of the roof is } \\
\text { crowned by the projecting cornice }\end{array}$} & $\begin{array}{c}\text { Presumably the wooden tent } \\
\text { lost of the tower. } \\
\text { The foundation is brick. } \\
\text { Typical project }\end{array}$ \\
\hline 9). Anzherskaya & \multicolumn{2}{|c|}{$\begin{array}{l}\text { The protruding structural consoles, } \\
\text { which are the support for the tank, } \\
\text { crown the tower around the }\end{array}$} & $\begin{array}{l}\text { Brick trunk, wooden tent. } \\
\text { Heated in the winter season. } \\
\text { Attic space. }\end{array}$ \\
\hline
\end{tabular}




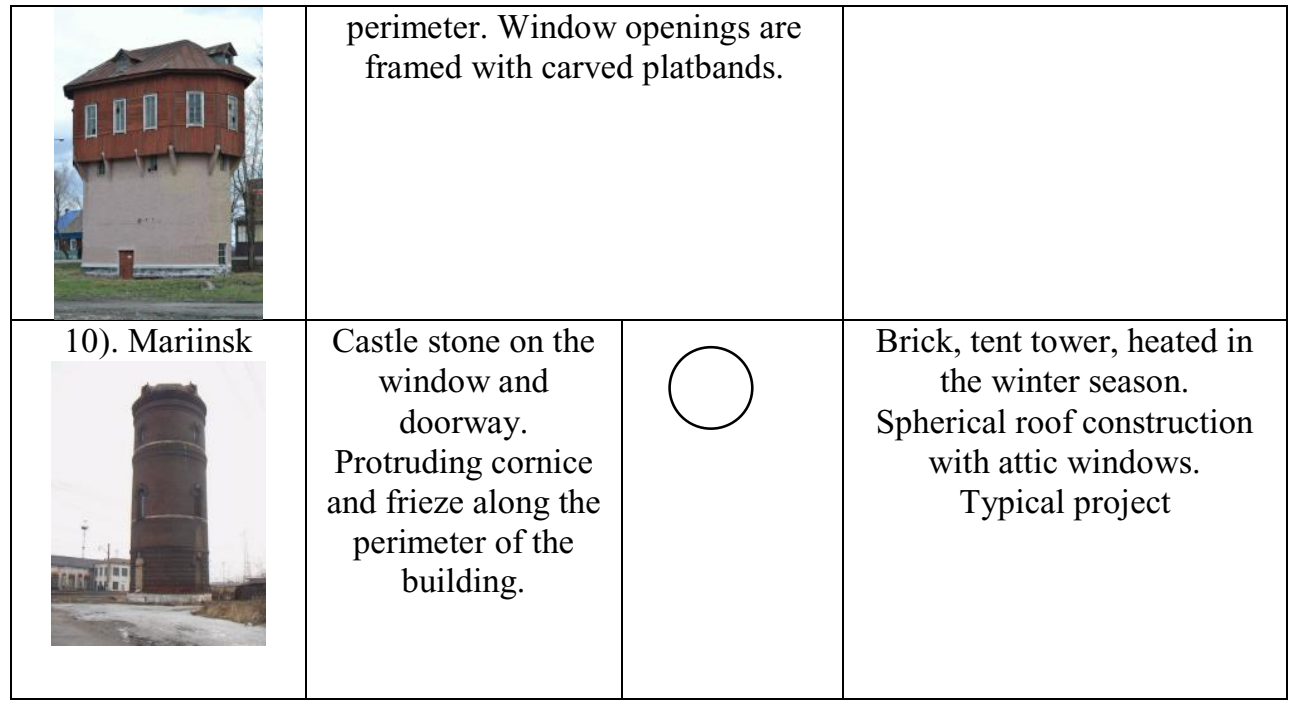

\section{Results}

The problem of water supply was one of the most urgent for most cities of the Russian Empire in the second half of the XIX century, primarily due to the nationalization processes in the country. The growth of cities and their residents' numbers required new technical solutions to this problem. At this time, many large cities are implementing projects for the water pipe construction.

The emergence of central water supply systems was preceded by local, departmental water pipelines. For example, there were two-lined water pipelines: university and railway in Tomsk in the late XIX century. The Siberian Railway in 1914 acquired a part of the Mariinsk city's land for the water communications construction. The distribution of railroad water pipes was very widespread, so clean water was necessary for steam engines. Therefore, partial water networks had many cities connected with railways. In 1910, the Russian Empire had 34 railways. Out of 16 , numbering $31,449 \mathrm{~km}$ of tracks had 1,417 water pipelines with a total daily consumption of about 500,000 $\mathrm{m} 3$ of water. In June 1893, the construction of the Omsk railway section began. Depending on the work volume, the stations are divided into extra-class, I, II, III, IV and V classes.

The station class is established on the basis of indicators characterizing its operation in conventional units. Extracurricular and class I stations include large sorting, freight and passenger stations. Intermediate, as a rule, belongs to the IV class. District and small freight stations are assigned II and III class. Let us consider in more detail the historically established stations of the Omsk-Mariinsk route.

Station Omsk. The station of II class historically located $3 \mathrm{~km}$ from Omsk. At the beginning of XX century, according to the structures size, occupied an outstanding place among the West Siberian Railway stations. In addition to the passenger station, more than 70 buildings were erected for railway needs

Station Tatar is of the IV class. The area is marshy, the water quality is not satisfactory, due to a poor source of water intake near the reclining pond, a frequent fever was observed.

Station Tebis is of the V class. The area is marshy with the lake water supply sources. Near the station there was a village native place. In the area of the station's influence, there were 14 villages. 
Station Kainsk is of the III class. The area is flat, marshy. Water supply was provided from the Lake Kalla. The station had a wooden church, a parochial school, a medical and nutritious resettlement center with barracks for 60 people. There is the city of Kainsk $12 \mathrm{~km}$ from the station.

Station Kozhurla is of the V class. The area is marshy, the water from the lake "Marova" is unsatisfactory, and in winter people use wells. Two settlements of Saint Alexandra and Peschaniy were formed at the station during its construction.

Station Kargat is of the V class. The area is sublime, water was used from the Kargat River, in the winter, and water was made from ice, because the river water became musty and yellow. There was a medical and nutritional station with barracks for 60 people at the station. A village of old peasants near the station on the bank of the Kargat River was formed.

Station Chulum is of the IV class. There was a buffet, the area was marshy, there was no water of proper quality. At the station, from the time of construction, a small town of small merchants and workers was formed.

Station Duplenskaya is the V class. The area is marshy, forest. Water is of good quality from the wells. There are 4 villages in the area of station influence.

Station Ubinskaya is of the V class. The area is marshy; the water supply is near the lake. There are 12 settlements in the area of the station influence.

Station Kochenevo is of the $\mathrm{V}$ class. The terrain is flat, dry. Water is of good quality from the wells. There are 7 settlements in the area of the station influence.

Station Novosibirsk is the main of the III class. The station is located on the right bank of the Obi River. Before the railway construction, the entire hilly coast was covered with a dense coniferous forest, descending along steep slopes to the vast water basin of the river. The station's buildings are spread out over the station's area. There was a vast stone locomotive depot (main depot) with small workshops for 450 workers at the station. Near the station there is a wooden church. On the other side of the station, closer to the river is a wooden school building for the children of railway workers. There is the railway workers' hospital near the school.

Station Tutalskaya is of the IV class. Station settlements grew up near the railroad, depots and other structures. In the course of the construction works, Yurga, (Yurga-1) railway station and a village station were built.

Station Taiga is of the III class. There was a buffet at the station. Taking a prominent place among the Trans-Siberian Railway other stations as a branch point, Taiga, despite of the environment unattractiveness, in the wild forests with scanty sources of water supply, attracted the population, both the resettlement and the old-timer, who formed a crowded village along the line. The station had no commercial value; the settlement population lived mainly due to earnings along the railway line. It should be noted that near the station they found small logs, which water supply value was negligible. Wells deepened at the station are not plentiful in water, and therefore it was necessary to bring water to the tanks to this vast station, both for feeding locomotives and for the population consumption.

Station Sudzhenka is of the V class. It is located near the Chandata river peaks, the river. Yai tributaries, in several best conditions of Taigi station water supply. Due to the richest reserves of coal and coal deposits, the station has a number of special values among others and was an important point of mineral fuel supply to the West Siberian Railway.

Mariinsk station is of the III class. There was a buffet. There is the Mariinsk town near the station, originally there was a small village "Kiiskoe", erected in 1856 in the city.

We considered the scheme of the railway station water supply at the beginning of the 20th century, before the modernization of the system.

The most common scheme for supplying the railway with water was presented in the following form: 
Water is supplied to locomotives' tenders of passing trains, a water supply system is being installed, provides various types of station equipment (steam locomotives, workshops, plants, etc.) at stations. It also provides the station's permanent population and temporary visitors with water for drinking and household needs and provides the water supply to extinguish fires. Sometimes, the water system is given tasks to supply villages, villages, etc. near the stations. The general scheme of the station water supply is shown in figure.

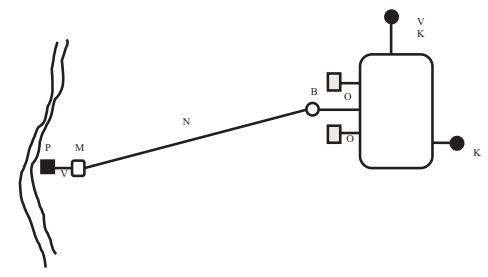

Fig. 1. General scheme of railroad water supply.

Water intake (gripping) structures $\mathrm{P}$ are located at the water supply source. A water pump $\mathrm{M}$ (a water-lifting building) is arranged near them, which pumps receive water by suction pipes from $\mathrm{P}$ and by pressure pipes (water pipe) $\mathrm{N}$ feed it into the water tower $\mathrm{B}$ (water reservoir) located on the station territory. Water enters to the network of distribution pipes $\mathrm{P}$ (a distributing network) from the tower water through tap, and other cranes installed on the pipes, $\mathrm{K}$ is dismantled. The noted scheme is the simplest and can be modified, sometimes with considerable complication, depending on the water quality. In the absence of water sources, water is delivered by trains from neighboring stations, on specially equipped platforms.

The railway station water consumption is different not only at hours of the same day, but also at the times of the same clock. During the water recruitment by locomotives from traveling cranes or extinguishing fires, water consumption is very large, during the periods when the station stops, it can fall to zero. Thus, the station needed to have some kind of reserve reservoir, which could supply a sufficient amount of water to the breeding network at the time of its greatest effect. Since the water needs to enter the network from the reservoir under pressure, it was located at an unknown altitude, determined by the magnitude of this pressure. In the absence of terrain natural elevation, which is typical for the West Siberian Plain, one has to resort to artificial rising of a reserve reservoir and install it on the walls of a high building of the water tower. Depending on the water amount required for the station, the number of tanks in the water tower may be more than one.

A) The shape of the tanks
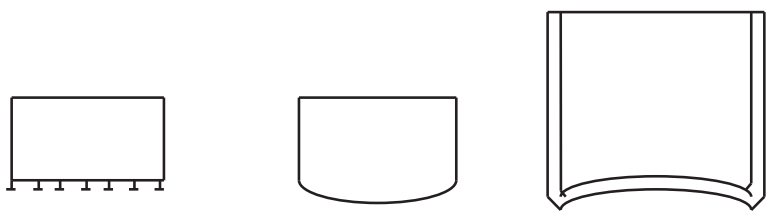

Fig. 2. Types of water-pressure structures tanks.

The simplest is a cylindrical tank with a flat bottom. The bottom of iron tank is on iron rolling I-beams placed at a mutual distance, and situating in turn on the water tower walls. Within the reinforced concrete tanks, the bottoms lie on the reinforced concrete ribbed ceilings of the tower. In view of this, tanks with a spherical bottom are convex. Sheets of 
convex bottoms are subjected to tensile stress that is why their application is rational for iron tanks.

B) General conditions for towers construction.

The tower was built of non-combustible materials. An exception could be made to the tent surrounding the tank. The tent was arranged with a wooden one, which made it possible to simplify, facilitate, and reduce the tower constructing cost. Against the fire of a wooden tent, roofing iron cladding was sometimes used.

To rise to the tank level, a staircase was necessary, it could be a screw, marching. It was necessarily to leave a margin of space between the roof overlap and the top of the tank. Below the earth surface, in the foundation part of the tower, it was necessary to arrange a mine, where manipulations were made with pipe latches.

Types of enclosing structures:

1. Brick water towers,

2. Reinforced concrete water towers,

3. Iron water towers.

Due to the severe climate in West Siberia, brick water towers with a wooden tent were mainly built, in order to avoid water freezing in the tank.

1. Brick water towers

The brick water tower is a tall building in a plan, usually as the form of a circle or regular polygon; sometimes the inner and outer outlines are not symmetrical, so it can be a circle inside and a regular polygon outside. The tent surrounding the tank is made from possible light but poorly conductive materials to reduce the weight of the structure. In relation to railroad water supply, brick towers have a greater advantage in terms of reconstruction and increase in barrel height to increase headroom.

2. Reinforced concrete water towers

Reinforced concrete water towers can be divided into two main types:

- The first type is the wall towers, which are erected from concrete hollow stones, and the only reinforced concrete are the tanks, inter floor ceilings, columns and other parts.

- The second type is tower erected entirely of reinforced concrete. There are polygons, round form tent, as a rule, in the tower plan. In addition, a roof lantern must be installed for natural lighting and ventilation

3. Iron water towers

The most popular were the water towers of Shukhov V.G. system. These towers are a revolution hyperboloid and composed of a very large number of angle section's straight racks, which are placed along the hyperboloid generators. All racks are fastened together by a height of several horizontal spacers from the corners. The mesh surface obtained in this way is a rigid system that strongly resists horizontal and vertical loading. Upper and lower construction ends with riveted rings. The upper ends of the posts are riveted to the upper ring; a reservoir is already installed on it. The reservoir is arranged in a wooden tent with an air layer.

\section{Discussion}

The analysis of the West Siberian direction made it possible to formulate a certain pattern of water-pressure structures' territorial location. An important aspect was the water source, it had to meet certain requirements for the possibility of its use, but mostly the stations were located in marshy areas where the water quality was not satisfactory. Therefore, there is a regularity in the water-supply structures increase at stations where water quality was satisfactory, as a rule, these were stations located on the shoreline of large Siberian rivers. This scheme allowed the reservation of water its transporting to stations that had been cut off from the water source. 
In addition, the West Siberian direction is dominated by the V class of stations, which indicates a large number of small stations with no maneuvering.

The analysis also showed it was necessary to have a water tank with the volume, which allowed feed the whole village in connection with the active construction of the railway line near the formed settlements.

Formed a unified typological base of water-pressure structures indicates brick-built with wooden tent predominance. This is understandable, because the Siberian region is rich in wood and it was cheap from the economic point of view and labor costs. It should also be noted that the influence of the "Siberian" style was reflected in these structures architecture. Roofs and lanterns were often crowned with carved wooden cornices. Window openings were always framed, and contained a castle stone or carved clypeus. The color solution typical for this region, the plastered trunk of the tower was painted in bright green or blue colors. The carved, stone decor was painted white, thereby highlighting and emphasizing it.

In conclusion, I would like to note that the analysis also made it possible to identify structures in critical condition and a threat, both for the environment and for humans. It is necessary to take measures for their repair or dismantling with the implementation of all measures for the environment sanitary protection. To avoid further cases, the author worked out the concept of these unique structures redevelopment.

\section{References}

1. A.P. Borodin, On water supply on the Railways, Moscow, 325 (1879)

2. N.N. Geniev, Water supply of railway stations, Moscow, 200 (1929)

3. R.B. Konchakov, Environmental aspect railway construction in 1860-1900s, RUDN Journal of Russian History (On the material of in Tambov Province), https://elibrary.ru/item.asp?id=1742787 310 (2012)

4. V.E. Vecher, The development of settlements in the Tomsk province under the influence of the Trans-Siberian railway at the turn of XIX-XX centuries, Vestn. Tom. gos. un-ta. Istoriya, 265 (2010). https://elibrary.ru/item.asp?id=15529611

5. Y.Y. Kurashov E.A. Maslova, Problems of preservation and use of cultural heritage railways (Part 2), Akademicheskij vestnik UralNIIproekt RAASN. https://elibrary.ru/item.asp?id=23011137 (2014)

6. L.F. Komyagin, Bessarabia unheated water facilities. Leningrad, 180 (1960)

7. A.A. Surin, Lifting, cleaning and storing water. Leningrad, 210 (1928).

8. I.K. Garkupov, Rural water supply of the Siberian region, Novosibirsk, 179 (1929) 